\title{
A IDENTIDADE LATINO-AMERICANA NA LITERATURA PÓS- MODERNA: As múltiplas confessionalidades no limiar da nação
}

\author{
Ricardo Araújo Barberena*
}

\begin{abstract}
LatinAmerican cultural landscape permeated by plural processes of symbolic and affective affiliation. In this sense, the past decade has been especially significant for the dissemination of texts marked by marginal subjects, obstructed by a migrating and crossing be/being. Among the many works that support these multiple confessions and memorials of the I, we will underscore texts such as Paulo Lins's Cidade de Deus, and César Aira's As Noites de Flores.
\end{abstract}

\section{KEYWORDS: identity, nation, migration, difference, representation}

Sob o inóspito mormaço porto-alegrense, no tenebroso verão de 2005, o Fórum Social Mundial despediu-se da capital gaúcha. Dentre as múltiplas manifestações culturais do evento, duas exposições, "Border Effects, Subjectivity and Public Spaces", de Mariana Silva da Silva, e "Deslocamentos", de Marie Ange Bordas, protagonizaram um especial momento-de-reflexão sobre o processo de afiliação simbólica e política das identidades nacionais. Tematizando o espaço limiar entre diferentes nacionalidades, "Border" instaurava um entre-lugar de representação no qual fotografias e vídeos argentinos, afegãos, palestinos, europeus e africanos se aproximavam de forma a reconstruir uma nova paisagem imagética declinada pela desconstrução das fronteiras do Estado-Nação. Nessa impactante instalação artística evidenciase um texto/tecido pluridirecional em uma justaposição narrativa de pertencimento identitário e de performatividades de uma subjetividade em migrância e parolagem. Em "Deslocamentos", por sua vez, concebia-se um projeto multidisciplinar focado nas experiências vividas por refugiados em variados lugares do mundo. Resgatando os relatos orais através de oficinas de imagem, o projeto expunha, dentro e fora das comunidades, depoimentos de refugiados de albergues em Johannesburg (África do Sul), Massy (França) e Kakuma (Quênia). Ao percorrer a instalação, percebia-se que as salas estavam dispostas de maneira a se experimentar um percurso inspirado na trajetória da maioria dos refugiados - uma trajetória definida pela quase impossibilidade de retorno. Transitava-se, então, mesmo que em breves passadas, pelo desassossego da incomunicabilidade do ser/estar em um não-lugar, não-territorialidade, nãosigno, não-institucionalização: uma retórica do des/caminho, da anti-ontologia da identidade cêntrica e presencial.

Parece bastante coerente que alinhemos estas duas exposições à pluralização identitária que descentra e fragmenta a ideia de nação. Mas uma questão necessariamente deve ser lançada: para onde nos leva a constatação da heterogeneidade? E mais: quais são as consequências epistemológicas e simbólicas? Uma primeira resposta poderia ser enunciada: o direito de desconfiar. Sim, o direito de desconfiar. Essa é uma das consequências de se assumir uma postura que desconfie dos sistemas nacionalistas coercitivos. Ao se colocar na berlinda uma lógica nacionalista que rechaça a diversidade cultural e a inclusão, problematiza-se uma

\footnotetext{
* Professor da Pontifícia Universidade católica do Rio Grande do Sul (PUCRS).
} 
perspectiva ideológica de exclusividade, majoritarismo e purificação nacional. Em outras palavras, diríamos que, ao desconfiar de tais preceitos de homogeneização, estamos, por decorrência, desaprovando o constante flerte sócio-político entre o radicalismo nacionalista e o racismo. Na medida em que as forças de totalização são debatidas, torna-se possível desestabilizar certos preceitos ultranacionalistas pautados pela busca de uma dada essência nacional. E aqui, desde logo, uma premissa precisa ser elucidada: o conteúdo deste nacionalismo está marcado em um bloco de poder que se apodera das figurações nacionais para constituir sua própria hegemonia. Assim sendo, cada nacionalismo se encontra referencializado em uma determinada conjuntura histórica atravessada por uma classe, uma raça e um gênero dominante. Diante dessa desconfiança perante as representações de uma nação pura e hegemônica, lança-se mão de uma postura crítica que esteja atenta à superfície híbrida e fragmentada de uma identidade nacional não mais enrijecida pelas fronteiras do essencial/exótico, do nativo/estrangeiro, do natural/esquizoide, do centro/periferia. $\mathrm{O}$ ato de reconhecer a heterogeneidade, portanto, mais do que assumir um compromisso teórico, pressupõe uma metodologia de leitura que desconfie das representações da nação enquanto reflexos de uma superestrutura amarrada por construções políticas, culturais, raciais, linguísticas monolíticas:

A representação da diferença não deve ser lida apressadamente como reflexo de traços culturais ou étnicos preestabelecidos, inscritos na lápide fixa da tradição. A articulação social da diferença, da perspectiva de minoria, é uma negociação complexa, em andamento, que procura conferir autoridade aos hibridismos culturais que emergem em momentos de transformação histórica. O direito de se expressar a partir da periferia do poder e do privilégio autorizados depende da persistência da tradição; ele é alimentado pelo poder da tradição de se reinscrever através das condições de contingência e contrariedade que presidem sobre a vida dos que estão na minoria (BHABHA, 1998, p. 21).

Como elemento-chave nesse processo de reivindicação de uma identidade nacional descentrada, as narrativas literária contemporâneas introduzem um arcabouço imagético que aponta para confluências identitárias inscritas em um contracânone em dissonância em relação aos emblemas de uma cultura nacional unificada. Se admitirmos que essas narrativas se articulam sob uma diversidade cultural que é parte atuante nas diferentes instâncias políticosimbólicas, cabe, então, levantar um outro ponto de discussão: qual é a figura de nação que emerge das representações propostas pelo texto/tecido. De imediato, propomos uma resposta: desenha-se uma nação sob a rubrica da travessia. Em incessantes deslocamentos, deflagra-se a constante migração de uma identidade nacional que não pode ser resumida em posições estáveis que essencializem os valores e os significados de uma brasilidade. Afinal, dentre esse manancial diegético e imagético, ecoa uma erosão interna pronunciada através de uma política representacional que se mostra aberta ao reconhecimento das minorias sociais. E aí se desencadeia a travessia entre o "lá e o cá", o arquivo-olvidado e o rosto renascido. Poderíamos aqui apregoar uma hermenêutica da errância: um deslocamento mítico-simbólico que se aproxima do porvir da própria linguagem. Mas essa nação que se move através da sua diferença cultural não deve ser confundida como uma forma de absolutizar a alteridade por intermédio de um aglomerado pluralista e apolítico. O que está em jogo não é um relativismo que oblitere as relações reais de poder em nome de uma noção nivelada de multiplicidade na qual todos se caracterizam como "outros", pertencentes a um grupo subalterno qualquer. Quando nos referimos ao deslocamento da nação, estamos na verdade mencionando o remapeamento de um tradicional conceito de nacional que enquanto formação cognitiva baliza uma alegoria de coletividade homogênea. Antes de trivializar uma versão celebratória das diferenças, procura-se avaliar a mobilidade e a não-fixidez da migrância das narrativas sociais e culturais que fornecem 
imagens, cenários, símbolos e histórias, representativas do sentimento imaginário de realidade compartilhada e coexistente:

Nenhum local, seja lá ou aqui, em sua autonomia fantasiada ou indiferença, poderia se desenvolver sem levar em consideração seus "outros" significativos e/ou abjetos. A própria noção de uma identidade cultural idêntica a si mesma, autoproduzida e autônoma, tal como a de uma economia auto-suficiente ou de uma comunidade política absolutamente soberana, teve que ser discursivamente construída no "Outro" ou através dele, por um sistema similaridades e diferenças, pelo jogo da différance e pela tendência que esse significados fixos possuem de oscilar e deslizar. O "Outro" deixou de ser um termo fixo no espaço e no tempo externo ao sistema de identificação e se tornou uma "exterioridade constitutiva" simbolicamente marcada, uma posição marcada de forma diferencial dentro da cadeia discursiva (HALL, 2006, p. 109).

Pensados nestes termos, estes eixos narrativos da pós-modernidade literária tecem um contradiscurso no que se refere aos índices de uma nacionalidade na contemporaneidade, cunhada sob a névoa da pertinência do projeto romântico. Tais narrativas se comportam como espaço e tempo de subversão à lógica hegemônica que propaga valores de "transcendência" artística e nacional. Daí o estabelecimento de um conjunto de significados e códigos que trabalham em um campo imagético antes renegado ao esquecimento e ao distanciamento em relação aos valores oficiais de uma dada nacionalidade. Com uma capacidade de expor uma área de recalque e exclusão, escritores como Nélida Piñon, Fernando Bonassi, Marçal Aquino, Paulo Lins, César Aira, Alberto Fuguet e Efraim Medina Reyes expõem uma pluralidade identitária que atravessa a negociação e o trânsito de objetos político-culturais existentes no interior da identidade latino-americana. No interior deste saudável desconforto identitário, podemos começar a nos questionar onde acabam e onde iniciam as imagens com as quais devemos (ou podemos) nos identificar. Ao projetar uma outridade que não foi imaginada por determinadas representações tidas como verdadeiramente nacionais, esses objetos culturais capacitam o reconhecimento de um poder simbólico também articulado em segmentos sociais à margem do status quo vigente. Pensar uma identidade nacional também vivenciada na sucessão de imagens e saberes não-dominantes é fundamental para que se possa admitir uma brasilidade urdida por sua diversidade e heterogeneidade de conhecimentos, classes, raças, valores. Nesses diferentes escritores, uma mesma motivação está presente: o desejo de reler a nossa identidade através da apresentação de uma parte da História que havia sido calada (ou ocultada) por uma lógica coercitiva e dominante.

Há que se atentar para efetivas decorrências desse ato de recontextualizar novas concepções sobre a nossa identidade nacional. Ou seja: quais são os efeitos, em nossa agenda curricular e educacional, no caso de se assumir uma definição de nação atravessada pela desterritorialidade e pela diferença cultural? Tomar consciência de uma diferença cultural urdida no interior de cultura nacional não é um movimento crítico-teórico tão tranquilo quanto pode parecer em uma primeira mirada. Como primeiro entrave epistêmico, ergue-se uma herança derivada de uma longa tradição cultural institucionalizada e convencionada nos moldes de uma literatura nacional inserida em um determinado cânone e em uma respectiva historiografia. Desse modo, torna-se eminente a necessidade de um revisionismo no que se refere às premissas de valor-verdade na formação de uma identidade nacional orientada por uma suposta ancestralidade de um passado pretensamente imutável. Neste flanco revisionista, reside a principal investida desse tropo crítico que se mostra voltado para a constante fragmentação das identidades no tocante aos influxos internos das múltiplas "memorialidades" latinoamericanas, afinal: 
Todas as mudanças profundas na consciência, pela sua própria natureza, trazem consigo amnésias típicas. Desses esquecimentos, em circunstâncias históricas específicas, nascem as narrativas. Depois de passar por transformações emocionais e fisiológicas da puberdade, é impossível lembrar da infância (ANDERSON, 2008, p. 278).

Revisitar a univocidade canônica materializa uma porta-de-entrada para o entendimento da engrenagem narrativa-valor-identidade na efetivação dos mecanismos de mitificação e eleição de certas representações como ficcionalizações fundacionais. Entendemos, por consequência, que o estudo de narrativas como os romances A república dos sonhos (1984), de Nélida Piñon, Cidade de Deus (1997), de Paulo Lins, Cabeça à prêmio (2003), de Marçal Aquino, Passaporte (2001), de Fernando Bonassi, As noites de flores (2004), de César Aira, Os filmes de minha vida (2003), de Alberto Fuguet, e Técnicas de masturbação entre Batman e Robin (2005), de Efraim Medina Reyes mostram-se pertinentes justamente nesse processo de releitura de uma identidade nacional não mais orquestrada por um sentido de fixidez identitária. E se poderia questionar se tal estratégia crítica pretende decretar a falência da nação enquanto pertencimento estável e centralizador. Diante tal indagação, responderíamos que essa nova estratégia crítica talvez não implicasse na completa derrocada do tradicional conceito de nação coercitiva, mas, sim, na instauração do direito à relativização epistemológica perante o caráter metonímico e essencialista da nacionalidade. Ao propor uma maior abertura curricular aos objetos culturais historicamente comprometidos com séculos de apagamento, esta postura revisionista fixa terreno em uma incursão pedagógica norteada pela releitura das fraturas entre as representações culturais da identidade nacional e a realidade do país. Assim, parte-se de uma agenda teórico-crítica preocupada com uma alteridade que se desloca em diferentes instâncias de debate político e representação de uma identidade nacional caleidoscópica.

Interrogar a continuidade progressista de um nacionalismo estreito que se articula sob as égides das exclusividades linguísticas, culturais e étnicas resulta, em termos práticos, na defesa de princípios acadêmicos pautados pela discussão acerca de uma solidariedades políticas multilíngues, multiconfessionais, multirraciais. Assim, acredita-se na precariedade do ato de unificar e purificar uma nação atravessada por múltiplas seitas religiosas, literaturas, tradições, danças, músicas, línguas. E os objetos culturais aqui discutidos contribuem para que se possa refletir a respeito de uma nação permeada por uma diferença cultural expressada nas lutas reais e cotidianas dos grupos minoritários - sejam elas vivenciadas no apartaid social dos eusmigrância da Cidade de Deus, sejam elas tingidas nas cintilações do eu-imigração de um temerário Passaporte, matizado por vistos visceralmente aleatórios. À medida que se admite que o sujeito nacional pode ser não-masculino, não-branco, não-burguês, abre-se um leque crítico que passa a contestar um ensino de Letras que se caracteriza enquanto ferramenta pedagógica limitada à propagação dos valores do estritamente literário, inserido em uma história literária legitimada. Então, se nos resumirmos ao rigor objetivista dos preceitos literários, incorreremos no perigoso erro de desvincular a literatura das crises e dos combates de uma cotidianidade marcada por várias esferas de poder e por múltiplos pertencimentos identitários. Há, portanto, que se perceber os textos literários como estratégias de narrativização de uma dada identidade agenciada por uma determinada classe, raça e gênero. E, ao se desestabilizar o estatuto literário da sua pretensa condição de sublime metafísico, a literatura passa a ser analisada apenas como uma narrativa entre tantas outras, sendo que sua particularidade está inserida em um deslocamento difuso de linguagens e representações. Como se sabe, essa tensão entre limite e transgressão do literário possibilita o reconhecimento das práticas de investigação de natureza interdisciplinar, pois a atividade crítica não pode ser entendida como um processo desassociado da sua função de mediador perante, pelo menos, dois meios de expressão. Assim, viabiliza-se a inclusão de novos objetos culturais que proliferam os entrecruzamentos entre literatura e outros sistemas semiológicos. Para se pressupor essa redefinição dos limites disciplinares, é preciso que se redefina o próprio objeto de análise pela ótica da descontinuidade como uma visão não-linear, não-cesural e não-cumulativa da história. 
Partindo dessa perspectiva, o ensino de literatura irá começar a trabalhar com as noções de corte, transformação, limiar, caracterizando-se um visível antagonismo perante àqueles antigos pressupostos teóricos que buscavam seguir as curvas evolutivas $\mathrm{e}$ as tradições institucionalizadas. Se é fundamental que admitamos a transterritorialidade nacional e cultural, também não é menos pontual que passemos a vivenciar um pragma e um ethos acadêmico que possibilite uma efetiva migrância disciplinar. E isto quer dizer várias coisas: além da falta de modelos e limites previamente fixados, se aceita o entrecruzamento dessas instâncias discursivas como uma possibilidade de retraçar territorialidades literárias e não-literárias. Esse debate autoriza a releitura de um feixe de pressupostos críticos presentes na história oficial, introduzindo-se um questionamento perante certos conceitos etnocêntricos como os critérios de filiação, de hereditariedade, de fonte e influência. Neste quadro de reorientação crítica, os estudos culturais protagonizam na procura de uma ultrapassagem dos limites disciplinares através de uma série de reflexões que focalizam os trânsitos e confluências entre gênero, etnia, classe. Constrói-se, então, uma metodologia de leitura que se mostra atenta ao jogo oscilante de secularização/desvalorização/reinvenção dos mitos nacionais dentro de um quadro social marcado por identidades tensionadas por uma realidade divida entre o transnacional e o regional. Além disso, o presente trabalho resulta na crença na mobilidade do remapeamento das identidades territoriais em uma perspectiva de fluidez e flexibilidade das fronteiras nacionais: afinal, aquele antigo discurso universalista encapsulador está abalado por uma necessidade de transpor espaços totalizantes e por um diálogo articulado no limiar dos textos, das culturas, do tempo, dos símbolos. Quanto a estas novas geografias identitárias, cabe lembrar como vários países da América Latina (Peru, Colômbia, Bolívia etc.), nos últimos quinze anos, têm estabelecido um conjunto de mobilizações e protestos político-culturais, objetivando um desafio da territorialidade do Estado perante o surgimento de novas formas de subjetivação/identificação espacial em uma associação entre descentralidade e democracia.

Passemos, então, a determinadas exemplificações romanescas acerca de uma identidade nacional submetida às clivagens de toda ordem. O romance $A$ república dos sonhos, de Nélida Piñon, problematiza as infindáveis travessias e descaminhos de uma brasilidade, perdida nos seus desejos/ânsias de justiça, trabalho, igualdade. Mas esses sonhos brasileiros também são os sonhos dos Outros, pois, ao se desenrolar a narrativa, fica evidente a presença de outras identidades imigrantes e diaspóricas (seja em personagens asiáticos, seja em personagens europeus). Fardo onírico, o Brasil comporta-se como terra de encontros e migrâncias entre histórias venturosas e deslocamentos trágicos. Como uma grande colcha de retalhos, o romance desnuda uma história social brasileira atravessada pela oscilação intercambiante de múltiplos segmentos identitários e culturais. Através da personagem Breta, consolida-se a imagem de uma mulher brasileira que desconstrói as cristalizações patriarcais e burguesas. No interior da família Madruga, essa personagem reorienta um espaço de luta identitária que em muito se assemelha às conquistas das mulheres na contemporaneidade nacional. Há que se atentar também para as questões de raça na obra de Nélida Piñon. A personagem Odete, empregada da família Madruga, é uma afro-brasileira que preserva as tradições dos seus antepassados afros. Entretanto, Eulália e Madruga, imigrantes da Galícia, têm um juízo estereotipado e eurocêntrico em relação a este Outro não-branco: ainda no início, o ativo cheiro das axilas de Odete forçava Madruga a abandonar a mesa quando a tinha por perto. E, por tal incômodo, quis dispensá-la. A personagem Eulália presentifica um desejo de dominação e "domesticação" da raça negra, e, em última instância, do Brasil mestiço, híbrido, plural. Na contramão, Breta revela sentimentos pontuados por uma respeito à alteridade afro no tocante à constituição étnica nacional: Breta veio-lhe ao encontro insuflando-a a crer que se não fora a presença africana entre nós, seríamos hoje irremediavelmente déspotas e sanguinários. Além disso, Breta é a personagem que será revolucionária não somente na família Madruga, pois, como ativista de esquerda, irá se engajar na luta de milhões de pessoas contra a ditadura militar e contra o AI-5. Já a personagem Esperança, filha de Madruga e Eulália, corporifica um processo-de-aprendizagem quanto à sua própria consciência de condição de mulher em oposição às castrações impostas pela sociedade. Nesse quadro familiar, Tobias, filho mais novo, incorpora um forte discurso quanto à 
problemática da reforma agrária, da exclusão social, e da opressão das minorias no Brasil pós68. Em termos narrativos, o romance relega, luckacsianamente, as personagens históricas a papéis secundários. Assim, esses intertextos em relação à historiografia instauram um posicionamento crítico no que se refere à história oficial da nação. Emerge, isso, sim, uma narrativa como grande metáfora da nação brasileira, voltada para as posições-de-sujeito marcadas pela margem social e pela outridade. A história do Brasil passa a ser entendida como a história de vários Sonhos - sonhados em plurais versões e traduções. Espécie de devir onírico em espaço desterrado.

Já na ponta dos dedos de Paulo Lins, em Cidade de Deus, escorrem as tintas de uma cidade à sombra das edílicas topografias da capital carioca. Somos introduzidos no imaginário de uma terra-olvidada, de uma terra-arquivada, de uma terra-desterrada. O romance registra, quase que sob o timbre da etnografia, uma viagem através de um escopo étnico/racial/linguístico situado nas experiências e emoções caóticas de uma comunidade marginalizada. $\mathrm{O}$ espaço urbano na modernidade, como nos lembra Fredric Jameson, passa a ser interditado por mundos desiguais numa coexistência de pequenas demolições narrativas e simbólicas:

Essas são uma desigualdade e uma coexistência que também podem ser registradas com um sentimento de perda, como o que ocorria das pequenas mudanças parciais e nas demolições da Paris de Baudelaire, que serviam, quase literalmente, como correlativo objetivo de sua experiência da passagem do tempo (JAMESON, 2006, p. 99).

Há que se destacar que o próprio escritor se apresenta em uma condição de completa inserção quanto aos dramas e celebrações daquele mosaico humano: antigo morador da Cidade de Deus, Paulo Lins tem a vivência subjetiva do olho no olho, do calor da hora das palavras trocadas, dos matizes sígnicos nessas conexões de alteridade. Assim sendo, poderíamos definir esse texto como um dos primeiros romances etnográficos na literatura brasileira que se encontra pautado por um feixe de memórias pueris do escritor (ou, até mesmo, biográfico ou autobiográfico). Parto de uma premissa narratológica e epistêmica: um dos grandes méritos dessa obra reside na construção de uma detalhada pesquisa etnográfica que não busca convencer o leitor de que a sua narrativa se mostra amalgamada ao plano do real - do factual histórico, da verdade positivista, do relato determinista. Ao intercambiar etnografia e matéria lírica, o escritor ilumina uma imaginário periférico e violento, assombrosamente verossímil, que é permeado pela saga anti-épica de uma guerra urbana. A partir dessa perspectiva de focalização narrativa, não interessa mais qual das histórias foi inventada e qual foi recolhida nos dolorosos depoimentos gravados durante anos de pesquisa. Entre personagens reais e nomes fictícios, nesse acidentado relevo identitário, diversas vozes, em trágica dissonância, reconstroem múltiplas vidas e significados olvidados no interior de uma cultura dominante. Parece, agora, difícil continuar fazendo-se cegar perante aqueles trezentos mil moradores. Afinal, tudo havia sido iniciado no já distante ano de 1966 quando uma leva de favelados foi transferida precariamente devido às inundações nos morros cariocas. Ali, no bairro Cidade de Deus, lugar imêmore e distante, ergue-se uma comunidade assolada pelo medo, pela injustiça, pela alegria, pela não-trégua, pela fúria bacântica. Neste romance, então, o personagem é uma população inteira que busca um tênue equilíbrio entre a sobrevivência sobrepujada e o cotidiano ritmado pelos calibres 38. Nas bordas do Rio de Janeiro, nas bordas da nação brasileira, descortinam-se, finalmente, os valores de um grupo de refugos humanos em contraste àquela identidade branca, masculina, hegemônica:

Cidade de Deus deu sua voz para as assombrações dos casarões abandonados, escasseou a fauna e flora, remapeou Portugal Pequeno e renomeou o charco: Lá em Cima, Lá em Frente, Lá Embaixo, Lá do Outro Lado do Rio e Os Apês. (...) Os novos moradores levaram lixo, latas, cães vira-latas, exus e pombagiras em guias intocáveis, dias para 
se ir à luta, soco antigo para ser descontado, restos de raiva de tiros, noites da velar cadáveres, resquícios de enchentes, biroscas, feiras de quarta-feiras e as domingos, vermes vermelhos em barrigas infantis, revólveres, orixás enroscados em pescoço, frango de despacho, samba de enredo e sincopado, jogo do bicho, fome, traição, mortes, jesus cristo em cordões arrebentados, forró quente para ser dançado, lamparina de azeite para iluminar o santo, fogareiros, pobreza para querer enriquecer, olhos para vida, despistar da morte, rejuvenescer a raiva, ensanguentar destinos, fazer a guerra para ser tatuado (LINS, 1997, p. 17).

Nessa eloquente justaposição de imagens de uma subalternidade em tom vermelho (cor do barro batido, cor dos destinos ensanguentados), repercute-se a reversibilidade de uma amnésia social que se mostra amparada em tática de cegueira institucional e identitária. Incrustada nessa topografia do inusitado, percebemos uma espécie de neofavela, armada de becos-bocas, expandida por um imaginário da perdição e da rebeldia quanto às (des)conjunturas de uma estruturalidade em suspensão. É necessária, então, a discussão a respeito de outras formas de afiliação simbólica e afetiva: um mergulho no caudaloso rio avermelhado que corre pela Cidade de Deus e carrega areia, rãs, sonhos, signos, eus.

Na primeira década do século XXI, Cabeça a prêmio, de Marçal Aquino, evidencia uma narrativa policial que não se restringe às formas narratológicas desse tipo de literatura, pois, inegavelmente, percebe-se uma escrita arrojada que em muito se assemelha a uma literatura tout court. Esse escritor brasileiro contemporâneo investe em um rompimento quanto aos marcos do gênero policial, no tocante ao retratamento de um Brasil bárbaro e profundo, submerso em uma malha de paixões e desesperos humanos. A nervosa e inquieta narrativa de Aquino não se resume à descrição de uma realidade pulp de matadores e vítimas trucidadas. Há, isso sim, um timbre narrativo cru e direto que combina uma estrutura narrativa complexa e descontínua, repleta de avanços, de elipses vertiginosas, de intensos deslocamentos geográficos. Ao introduzir ambientes e personagens, o romance pontua um matiz textual presente nos tough writers norte-americanos - Raymond Chandler, James M. Cain, Dashiel Hammett. Quanto à sua concisão narrativa, alinhada à escrita de Hemingway, ressalto também os influxos do cinema no exercício da produção de diálogos ágeis que rechaçam qualquer tipo de floreio beletrista e ornamental. Na sua estrutura temporal, Cabeça a prêmio se encontra descentrado em dois tempos distintos nos quais se deslocam cinematográficos flashforwards e flashbacks. Em um desses tempos, dois matadores profissionais, Albano e Brito, planejam uma tocaia para arrebatar a vítima em questão. Já no outro locus temporal, um piloto tem uma relação amorosa secreta com a filha do fazendeiro-traficante que o emprega. Como nos scripts narrativos policiais, ao final da trama, todas as trajetórias-de-existência se entrecruzam. De uma forma ou de outra, todos os personagens têm a cabeça a prêmio em um Brasil atravessado por identidades em travessia e constante recriação.

Ressaltaríamos aqui, ainda na primeira década do XXI, o livro de Fernando Bonassi, Passaporte. De difícil conceituação narratológica, poderíamos, sim, defini-lo como uma espécie de texto/tecido no qual testemunhos se entrelaçam como fios de memória circunstancial e arbitrária. Em múltiplos relatos de viagem (travessias territoriais e existenciais), sobrepõe-se um mosaico fragmentado de lembranças sob uma matéria prismada pelo lirismo e pelo desassossego. Esses textos-hiato se organizam caoticamente (a folha é preenchida em múltiplas direções espaciais) em alegoria a desorientada marcação dos vistos-de-viagem em um passaporte. Cabe ressaltar, quanto à estruturalidade do livro, a sua absoluta parecença com um passaporte de viagem. Trata-se de um livro-passaporte no qual somos convidados a derivar sob um plano diegético intervalar no qual apenas podemos visualizar uma escritura de rastro e errância. De tortuoso trânsito e migração, esse texto literário exige quase que um diálogo fotográfico quanto ao seu potencial metafórico de edição e reificação. A cada página, ou seja, a cada carimbo-texto, migramos por uma esquina de Jiparaná, de Cuiabá, de Jardinópolis, de 
Munique, de Berlim Ocidental, de Hamburgo, de Miedzyrzecz etc:

002 tiradentes. No início dos anos 70, os garimpeiros arrancavam os seus próprios dentes. A sangue frio, é claro. De modo que quando Paulão viajou pro norte com uma bolsa cheia de Citanest teve sucesso imediato. Mesmo quando os veios de ouro secaram, Paulão continuou oferecendo anestesia (...) 005 pró-álcool. Jardinópolis não tinha asfalto. Nem zona aberta de dia. Os restaurantes serviam prato feito com feijão separado na cumbuca e sorvete vinha com pedaços de fruta. Depois chegaram as moscas verdes (....) 006 bahnhof zôo. Porque os trens estão fugindo de Berlim e as pessoas querem chegar sem sair, elas se beijam. Meninos, meninas, meninos/meninas se babam e se lambem às cãibras (BONASSI, 2001, s/n).

E é nesse fluir-de-Ser que se instaura uma imaginário (trans)nacional no qual parece impossível uma falsa linearidade causalística do navegar, do imaginar, do significar... Do (im)portar-se.

A escrita de César Aira, em As noites de flores, por sua vez, introduz uma cidade tentacular e labiríntica: Buenos Aires. Localidade que pode ser percorrida em diferentes velocidades. De vários pontos de vista, revela-se uma cidade diferente. Uma identidade diferente. Em oscilante ritmo - banal, verossímil, inverossímil, real, fantasioso, insólito articula-se uma narrativa-jogo que propõem mudanças de perspectivas a cada parágrafo. A cidade fantasmática e invisível reproduz uma população amedrontada pela criminalidade. E é nesses espasmos urbanos de um lugar de super-passantes que Aldo e Rosita Peyró, um casal de meia-idade que resolve entregar pizzas à noite no bairro de Flores. Além de despertar a curiosidade das pessoas pela idade pouco usual ao ofício, dominado por jovens motoboys, o casal também surpreende pela forma como faz as entregas - a pé. Sempre juntos, Aldo e Rosita descobrem durante as entregas um mundo novo, formado por figuras que talvez jamais pudessem conhecer no seu pacato dia-a-dia de aposentados de classe média - bêbados, travestis, prostitutas e outras figuras da noite. Em suas andanças com muitas pizzas quentinhas a tiracolo, o casal presencia o desenrolar do sequestro e posterior assassinato do jovem Jonathan, também entregador de pizzas. $\mathrm{O}$ caso detona uma série de atos ilegais nos quais estão envolvidos muitos dos personagens que acompanham Aldo e Rosita na noite de Buenos Aires. A narrativa, de forte potencial lírico, presentifica uma tierra de jornadas tautológicas e de caminhadas em suspensão pelos desassossegos noturnos de uma identidade mutante. Em determinado trecho, que reproduzimos logo abaixo, percebemos certo descritivismo alegórico no que se refere aos sentidos e as angulações do bairro de Flores:

Todas as ruas de Flores eram de mão única, ou de "sentido único", e todas se cruzavam em ângulos retos, em um quadriculado, como um tabuleiro de damas, sem variações. Antigamente, tinha sido uma área de fazenda e chácaras. Tinha se urbanizado tardiamente, já bem entrado no século XX, e daí vinha a regularidade. As mãos estabelecidas para as ruas deviam ser obedecidas pelos carros, caminhões, coletivos e, na realidade, por todos os veículos sobre rodas que circulassem pela rua. Não os pedestres, é claro, mas os pedestres circulavam pelas calçadas, nas quais não imperavam as mãos ou sentidos, exceto os da cortesia (AIRA, 2006, p. 58).

Sob a artificialidade retórica dos ângulos retos de Flores, constrói-se, então, uma identidade-rasura que atravessa esse grande tabuleiro de representação das regras de significação cultural. Impera, ao longo das páginas, uma força-motriz de ultrapassagem dos limites e das fronteiras dessa grande parábola da argentinidade que se configura no microcosmo 
do bairro de Flores. Essa pequena comunidade poderia ser entendida como uma metanarrativa de toda um Estado-Nação colocado na berlinda pelos particularismos identitários e pelas obliquidades dos "ângulos retos".

Em confluência às derrotas da narrativa de César Aira, a obra de Alberto Fuguet, $O s$ filmes da minha vida, apresenta-se como uma substância caudalosa e obtusa que desloca a literatura para o campo da sétima arte. $\mathrm{O}$ segundo romance do escritor chileno se encontra divido em cinquenta subcapítulos, nomeados com títulos de diferentes filmes. O enredo expõe o dolorido balanço que seu protagonista, o sismólogo Beltrán Soler, traça sobre a própria identidade a partir do falecimento do avô. As recordações pueris nos EUA e as lembranças no Chile, com tudo que as envolve - idiossincrasias familiares, dilemas ontológicos, dores e alegrias do amor - são despertas pela contemplação fílmica. Assim sendo, os filmes desfiam seu novelo de recordações; eles são as madeleines de Beltrán. Importam menos, portanto, o enredo ou a qualidade das produções, e mais o seu entorno, as situações que bordejaram o contato com as películas, rigorosamente fixado em local e data. Em alguns casos, os relatos são esboçados a partir do testemunho alheio, como acontece com "A história de Elza", o primeiro filme da lista. Beltrán tinha apenas 2 anos quando o viu, em um drive-in. Ele então se imagina no carro, junto com os pais e a irmã Manuela, que, saberemos depois, sequer havia nascido. A trama enredada através dos filmes é enriquecida com a reprodução de e-mails, a descrição de diálogos telefônicos, anotações esparsas e até um currículo do protagonista. Apesar dessa fragmentação, há certa linearidade na história narrada por Beltrán, sob a qual paira por todo o tempo uma analogia simbólica entre a explosão telúrica do protagonista e o ofício que exerce: o estudo dos abalos sísmicos. "Os terremotos são a maneira que a terra tem de se livrar de seus fantasmas" (FUGUET, 2003, p. 8), costumava dizer seu avô. A assertiva sintetiza a condição do próprio Beltrán, que aparentemente falhou naquela que acreditava ser paralelamente a missão e o pior defeito de um sismólogo: ver além, procurar fendas, detectar falhas e resistências para prever e evitar tragédias. A escolha dos filmes - a maioria bastante conhecida - e o sotaque pop do livro refletem uma das principais facetas da literatura de Fuguet:

Como cheguei a fazer uma lista com os filmes da minha vida? Como isso me ocorreu? Por que, depois que aterrissei no aeroporto de Los Angeles, me aconteceu o que nunca imaginei que aconteceria: não fiz outra coisa além de montar mentalmente uma lista atrás de outra. Como acabei percorrendo esta cidade interminável, no banco de trás de um velho Malibu verde, com um salvadorenho grisalho como meu motorista? O que me deixou enjoado nos corredores iluminados de uma loja cheia de seres solitários e obsessivos chamada DVD Planet? Por que voltei a pensar - a viver, a sentir, a gozar, a sofrer - com acontecimentos e pessoas e filmes que dava apagados (superados, eliminados) de meu inconsciente? Por que voltei a lembrar depois de tanto tempo? Por que, depois de anos sem ir ao cinema, de não ver absolutamente nada, retornei a meus tempos de devorador de filmes? Em outras palavras: What the fuck is going on? (FUGUET, 2003, p. 9).

Nesse visceral mergulho interior, o narrador elucida uma espécie de noia que extravasa uma oscilação poética sobre as indagações que nadificam um eu em desassossego, em rotação. É sempre propício lembrar Paul Valéry: "deve-se entrar em si mesmo armado até os dentes" (VALÉRY, 1997, p. 117). Ao tatear as inconcretudes do inconsciente, esse narrador, então, percorre um sinuoso itinerário pelos espectros das películas e pelos simulacros do próprio eu. Quanto ao projeto estético que potencializa essa condição de deslocamento identitário, é importante lembrar que Fuguet lidera o movimento McOndo, germinado em uma revista publicada na Espanha em 1996, e cujo nome remete, com ironia, à mítica cidade imaginada por Gabriel García Márquez. O McOndo proclama o fim do realismo mágico e a luta contra o clichê de uma América Latina folclorizada. Tal crítica ecoa em Os filmes da minha vida 
fundamentalmente quando o escritor explora o choque cultural que atinge Beltrán ao retornar a Santiago depois dos anos vividos na Califórnia. O olhar de estranhamento que lança em direção à cidade, o desejo de não ser parte daquilo, a dificuldade inicial com o idioma, tudo isto ressoa no romance, chegando às raias do satírico no episódio em que o protagonista registra o embevecimento dos compatriotas ao se sentirem parte do mundinho de Hollywood só porque o astro Yul Brynner casara-se com uma chilena. Ao expor a trajetória e os dilemas de Beltrán através de produções exibidas em todo o mundo, o autor efetiva sua crença em uma "nova sensibilidade artística", característica de "almas globais" que partilham produtos culturais comuns, como músicas e programas de TV. Assim, uma produção-catástrofe como "Terremoto" pode remeter Beltrán, além das impressionantes sequências de destruição, para o instante em que, ao enxergar a tez transparente do avô, compreendeu que ele estava velho. Os tesouros magníficos e a enormidade do oceano em "O fundo do mar" tornam-se pouco diante do plano em detalhe de Jacqueline Bisset nadando com os mamilos endurecidos sob a camiseta molhada. A frase "não estamos sozinhos", perdida no cartaz de "Contatos imediatos do terceiro grau", pode lembrá-lo de que o pai partira e, sim, ele está sozinho. E a vida banal de um jogador de tênis, em "Amor em jogo", fazê-lo enfim perceber que os filmes - e decerto também os livros - emocionam as pessoas, sobretudo quando falam sobre elas mesmas.

Ainda seria importante ressaltar, nesse cenário latino-americano, a colaboração importante de Efraim Medina Reyes, no livro Técnicas de masturbação entre Batman e Robin. Em vez de seguir a tradição do realismo fantástico, esse escritor surge como um dos mais autênticos representantes da literatura que vem sendo chamada de realismo urbano, ao lado de outros escritores latino-americanos como Mario Mendonza. Neste livro, o sexo é apenas pretexto para uma reflexão sobre os diferentes aspectos da vida, de cunho social, sexual ou existencial. Cabe ressaltar que Reyes é um dos mais celebrados jovens autores latinoamericanos. O protagonista, do romance em questão, é um publicitário, Sérgio Bocamole, que se divide entre o trabalho, que leva sem muito entusiasmo, e seus múltiplos relacionamentos. Frequenta festas com muita bebida, música e drogas recreativas. É um anti-herói por excelência, que reage aos movimentos da vida sem muito planejamento ou preocupação com o futuro. Apaixona-se por uma mulher excêntrica, Marianne, que se envolve com um açougueiro rude em busca de bruscas emoções. A narrativa é permeada por identidade sequencial. Elabora-se uma subjetividade sob a égide da ficcionalização do Eu: sob o estatuto de uma multidirecionalidade identitária, tornam-se enevoados os cartesianos contornos de normalidade/certeza/verdade.

E agora que se aproximam as últimas palavras desse ensaio, percebo (peço licença para finalizar nossa conversa na primeira pessoa) uma dessas ironias do imponderável acaso: essa redação recebe as suas tintas finais justamente em uma terça-feira de Carnaval. Data extremamente convidativa para uma reflexão acerca das narrativas suplementares de uma dada identidade nacional. Enquanto se sucedem inúmeras reportagens sobre aquelas festividades e alegorias "essencialmente" brasileiras, visito, pela última vez, os catálogos Deslocamentos dos refugiados dos diferentes pontos da paisagem humana global. Da exuberância das fantasias da Marques de Sapucaí aos tristes retratos em preto-e-branco, tal contraste cromático parece não pode passar impune a retina: seria a identidade cultural um agenciamento simbólico que necessita de uma esquize do olhar? Refugiados sociais ou ícones celebratórios dos trópicos? Protagonistas de um apartaid social ou embaixadores da fiesta da diferença? Parece que tais perguntas só podem ser respondidas se pensarmos nas nossas táticas de amnésia e cegueira. Afinal, a imagem, enquanto falta constitutiva, é produzida por uma esquize entre o olho e o olhar. Uma esquize entre o que é olhado no campo da representação "e aquilo que escorrega, que passa". Essa é a perversão do objeto. Olhamos sem ver. O desvelamento do vazio acaba nos descentrando. Quando, além do punctum bartheano, instaura-se um Outro significado, uma Outra narrativa, uma Outra miragem/migrância. E com a identidade latino-americana não é diferente. Por mais que nos cerquemos de uma unicidade imagética e cultural, existirão faltas constitutivas que propõe um campo escópico em esquize. Por mais que se articule um policiamento canônico, emergirão outros pertencimentos estéticos e identitários em dissonância suplementar. Continuemos, portanto, buscando espaços de discussão acerca de uma poética do 
desassossego. Uma diáspora do olhar.

\section{BIBLIOGRAFIA}

ANDERSON, Benedict. Comunidades imaginadas. São Paulo: Companhia das Letras, 2008. PIÑON, Nélida. A república dos sonhos. Rio de Janeiro: Tempo Brasileiro, 1984.

LINS, Paulo. Cidade de Deus. São Paulo: Companhia das Letras, 1997.

AQUINO, Marçal. Cabeça a prêmio. São Paulo: Cosac \& Naify, 2003.

AIRA, César. As noites de flores. Rio de Janeiro: Nova Fronteira, 2004

FUGUET, Alberto. Os filmes de minha vida. Rio de Janeiro: Agir, 2003.

JAMESON, Fredric. A virada cultural: reflexões sobre o pós-moderno. Rio de Janeiro: Civilização Brasileira, 2006.

MEDINA REYES, Efraim. Técnicas de masturbação entre Batman e Robin. Rio de Janeiro: Planeta, 2005.

BHABHA, Homi K. O local da cultura. Belo Horizonte: UFMG, 1998.

HALL, Stuart. Da diáspora. Belo Horizonte: UFMG, 2006.

VALÉRY, Paul. Monsieur teste. São Paulo: Ática, 1997. 